\title{
ELEMENTARY SCHOOL TEACHERS' PERSONALITY IN STUDENTS' LEARNING MOTIVATION TO UNDERSTAND CONCEPT OF SCIENCE
}

\author{
Lily Barlia \\ (Jurusan PGSD UPI Kampus Serang Banten, lilybarlia@yahoo.co.id)
}

\begin{abstract}
Abstrak: Kepribadian Guru Sekolah Dasar dan Motivasi Belajar Siswa untuk Memahami Konsep Sains. Penelitian ini ditujukan untuk menggali informasi faktor-faktor yang mempengaruhi motivasi belajar anak usia sekolah dasar untuk pemahaman konsep sains. Subjek penelitian adalah 26 anak SD kelas VI di SD RSBI Banten dan guru yang membelajarkannya. Metode pengumpulan data dengan angket tentang strategi motivasi belajar anak (MSLQ=Motivated Strategies for Learning Questionaires), observasi kelas, dan wawancara terstruktur. Analisis data dilakukan untuk mendapatkan gambaran tentang faktor-faktor yang mempengaruhi motivasi belajar, dan cross-case analysis untuk setiap anak. Hasil penelitian menunjukkan bahwa setiap anak mempunyai faktor motivasi yang berbeda dalam belajar sains. Kepribadian guru yang unik, seperti kedekatan serta berusaha untuk memahami dan menghargai potensi anak didik dapat meningkatkan motivasi anak belajar sains. Dapat disimpulkan bahwa di dalam proses pembelajaran sains untuk perubahan konseptual, seorang guru sekolah dasar harus memahami pentingnya faktor-faktor yang mempengaruhi motivasi anak untuk belajar, termasuk kepribadian yang dapat diterima, sehingga mereka dapat mengikuti proses pembelajaran dengan lebih bermakna.
\end{abstract}

Katakunci: motivasi, pembelajaran konseptual, perubahan konseptual, pembelajaran sains, kepribadian guru

\section{INTRODUCTION}

Research on students' learning in science has been conducted for several decades. From this research, a model of student learning, the Conceptual Change Model, was proposed by Posner et al., (1982). This learning model has been the focus of much attention and research in science education community (Beeth, 1998; Beeth \& Hewson, in press; Pintrich, Marx, \& Boyle, 1993). The authors of the Conceptual Change Model (hereafter referred to as the CCM) view an analogy between students' conceptual learning in the classroom and the process of conceptual change in the science community. The CCM views student learning as a rational process analogous to the way in which many contemporary interpretations in history and philosophy of science picture change in the knowledge of scientific communities. Thus, scientific knowledge is constructed based on the learners' current understanding of a phenomenon and the impact of new information or new ways of thinking about 
existing information that bear on a phenomenon.

Despite the fact that the CCM is widely accepted and has had considerable influence in science education research and curriculum development, science educators are still confronted with students who are unmotivated to work toward achieving scientific understanding. Many students spend their time and effort focusing on less important learning outcomes such as memorizing science vocabulary or factual information, rather than trying to achieve conceptual understanding (Anderson \& Roth, 1989; Blumenfeld \& Meece, 1988). In addition, they also rely on inadequate explanations for science concepts by distorting scientific knowledge to fit their existing knowledge, mindlessly answering questions, or copying answers from the texts or peers (Anderson \& Roth,1989; Blumenfeld \& Meece, 1988). In addition, drilling of the item tests preparing for the national final examination greatly contributed to getting worst of students' conceptual understanding in science. This raises a concern among science educators about how to stimulate student motivation to learn science when the teacher teaches for conceptual understanding.

A number of criticisms have been directed at the model. One specific criticism of the CCM is that it lacks attention to affective aspects of learning, including motivational constructs (Pintrich, Marx, \& Boyle, 1993). They argue that the CCM presents a highly rational view of learning (being driven solely by logic and scientific thinking) with little or no reference to motivational cons- tructs such as goals, value beliefs, or self-efficacy beliefs. Indeed, Strike and Posner (1992) in a recent response to Pintrich, Marx, and Boyle's criticism of the CCM indicated that the affective factors are an important area that should be investigated.

Pintrich, Marx, and Boyle (1993) and Boyle, Magnusson, and Young (1993) believe that student motivation is an important factor that can lead to raising or lowering the status of a conception. For instance, accepting the fruitfulness of a new conception implies a role for students' value judgments about the applicability of a conception as well as his or her goals for learning, such as how new information might help in attaining a desired end. On the other hand, learning portrayed by the current CCM focuses only on student cognition without considering students' motivational beliefs about themselves as learners and their roles in the classroom community. This limited view of learning does not offer a complete picture of the process of conceptual change learning. Thus, the importance of considering student motivational beliefs in the process of student learning is essential to engaging students in conceptual change learning. This is to say that the process of conceptual change is influenced by personal, motivational, social, and historical processes (Cobb, 1994; Driver, Asoko, Leach, Mortimer, \& Scott, 1994; Pintrich, Marx, \& Boyle, 1993).

\section{METHOD}

This study attempted to bring together research on students' motivation with research on conceptual change 
learning in science with a specific goal to investigate the relationships between motivation factors profile and students' engagement in conceptual change learning in science. One of the research questions examined in this study is: How did the teacher's personality promote students' motivation when learning science?

The study was conducted for two weeks (14 days) in the first semester during the 2008/2009 academic school year on a sixth grade of the elementary school prepared for international standard (RSBI = Rintisan Sekolah Berstandar Internasional) located in Banten, where the teacher (Mrs. ED) implemented principles of conceptual change instruction through her daily classroom activities. Twenty students were selected for this study, represented three academic achievement levels (i.e., high, middle, and low), and both genders. Data collection for this study included: (1) Student's self-reported responses to the translation of the Motivated Strategies for Learning Questionnaire (MSLQ), (2) classroom observation of students and the teacher, and (3) structured interviews. The Motivated Strategies for Learning Questionnaire (MSLQ) is a self-report instrument. It has been under the development formally since 1986 when NCRIPTL (National Center for Research to Improve Post-secondary Teaching and Learning) was founded. The Motivated Strategies for Learning Questionnaire (MSLQ) that was used in this study is the version in which the Cronbach's alphas are robust, ranging from .52 to .93 (Pintrich et. al. 1991). These indicate that data obtained on the MSLQ show reasonable factors of validity.

Direct classroom observation of teaching strategies and student's behavioral engagement in learning science was focused on (1) the sequence of events that the teacher presented to students, the strategies that the teacher uses, and the materials presented during a science lesson, (2) students' responses to the teacher instruction, and (3) instances when the motivational behaviors were presents.

Interviews were guided by a structured format. Each interview was conducted for the selected individual once a week lasting between 10 and $15 \mathrm{mi}-$ nutes focused on (1) obtaining information on motivational factors that are not elicited through the self-report questionnaire (i.e., a student's specific goals orientation of learning science as well as other factors influenced to his/ her motivation to learn), and (2) validating findings that were resulted from a student's self-report and observations.

The data analysis procedures are intended to analyze information related to the research questions. Three general steps of data analysis are used: (a) analysis based on intuitive reasoning from a complete reading of data, (b) analysis using a rating or frequency counts, and (c) developing case studies. Analysis of these data resulted in the motivational factor profile for each student and cross-case analysis for entire of the study participants. 


\section{TEACHER'S PERSONALITY AND STUDENTS' MOTIVATION}

The findings generally can be described that the Instructional strategies and students' motivational factors contributed to their engagement in learning for understanding. Instructional strategies that were implemented based on conceptual change teaching and students' motivational factors such as goals, values, self-efficacy, and control beliefs provided crucial effect on the quality of student engagement in learning activities. The findings suggest that both of traditions, students' motivation and conceptual change approaches to learning science have the important implications for those who wish to improve science teaching/earning.

The teacher's interaction with the individual students in ways that would help students to more motivated strategies to engage in learning within social contexts of the classroom seemed to be the important factor to be considered by the teacher in daily teaching-learning activities. In other words, it is crucial to bring together issues of student motivation and conceptual change learning as suggested by Barlia and Beeth (2002), Boyle, Magnusson, and Young (1993). In summary, student motivation can be a crucial factor that should be considered to maximize student engagement in learning for conceptual change. The followings are the examples of how the elementary school teacher's personality contribute students' motivation to engage in conceptual change learning in science, especially for students categorized in the middle and lower level on academic performance.
$\mathrm{RZ}$ is one of the students who placed in the low academic achievement level of Mrs. ED's class. He sometimes got difficulty to understand science concepts offered by the teacher. In the following statement, RZ explained what he does when he encounters difficulty in learning a science concept.

Before asking to the teacher, I do asking to my very closely friends who understand the material. I seem to understand things better when a group of us get together and work out things we don't understand as a group efforts. After that, I would ask my teacher if I really don't understand difficult concepts or materials (RZ).

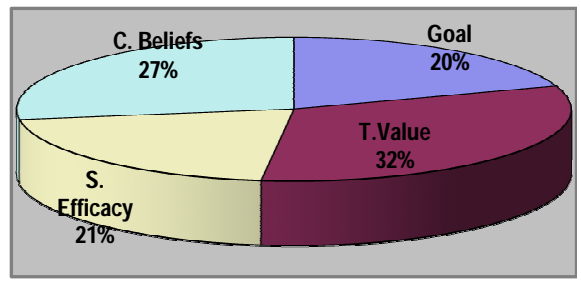

Figure 1. RZ's Motivational Factor Profile

RZ's motivation to learn science consists of $27 \%$ control beliefs, $20 \%$ goal orientation, $32 \%$ task value, and $21 \%$ self-efficacy. Task value comprises the largest portion of RZ's motivational factor profile (see Figure 1). It indicates that he has positive perception of hard effort in learning will lead him to get a good grade. Compared to the overall mean of the class, RZ's motivation score is slightly below that of the class ( 5.3 for RZ compared to 5.6 for the class).

In his explanation, RZ indicated several strategies of learning science such as discussing with her friends and asking the teacher. The researcher probed RZ's response by asking what he 
does outside of the classroom to help him learn science better. $\mathrm{RZ}$ responded with comments about a study party, doing homework, and asking for extra explanation from the teacher including asking some strategies he undertook to learn science.

In Mrs. ED's classroom, ST is one of the students categorized in the lowest academic achievement level. She frequently faced difficulty understanding the science materials that the teacher offered. From several responses of my questions, I concluded that she is one of the students who less motivated to learn science. The following statement reflects ST's efforts outside of the class in order to help her learn science better. She did not hesitate to ask the teacher when she had difficulty understanding the science contents. This implied that the teacher was very open and always ready to help students as they need.

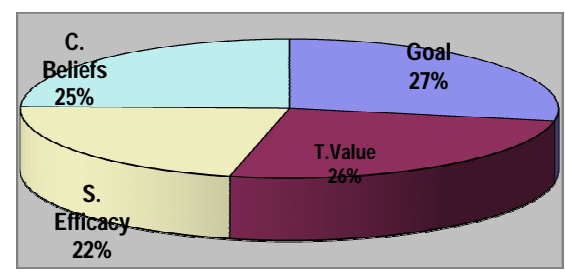

Figure 2. ST's Motivational Factor Profile

$\mathrm{ST}^{\prime}$ 's motivation to learn science consists of $25 \%$ control beliefs, $27 \%$ goal orientation, $26 \%$ task value, and $22 \%$ self-efficacy. The percentage of her motivation factors (control beliefs, goal orientation, task value, and self-efficacy) to learn science almost the same (see Figure 2). It means that her motivation to learn science is the lowest among that of her classmates. In other side, because of Mrs. ED openness to her, she developed own learning strategies to get better understood science materials.

I and two other students of my closely friends frequently had a study group!! I also do the homework assigned and I study for the tests. If I am having problems to understand the science materials offered, Mrs. ED is there for some extra explaining before or after school. She really patient to have me understood (ST).

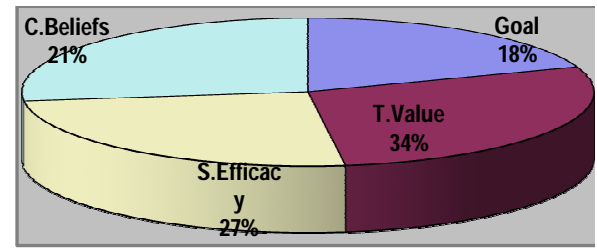

Figure 3. AK's Motivational Factor Profile

AK's motivation factor to learn science consists of $21 \%$ control beliefs, $18 \%$ goal orientation, $34 \%$ task value, and $27 \%$ self-efficacy. He put very low in goal orientation as his motivation factor to learn science (see Figure 3). It indicates, he does not really know the goals he wants to reach by learning science. Compared to the overall mean of the class, AK's score is slightly above that of the class (6.1 for AK compared to 5.6 for the class).

In his class, $\mathrm{AK}$ is categorized as a middle academic level student. He believes that his succeed in learning science is due to the ways of Mrs. ED's teaching that encourages him to learn science for understanding: 
Sometimes, I got discouraged with some new science ideas. I always try to focus my thought to the problems. I relate them to my everyday life. Mrs. ED will try hard to explain them and she will help me understand and encourage me. I am not giving up until I understand. Also, my motivations are myself and always trying to do the best I can do. In fact, science is one of the courses that will be offered in the national examination. So, I am motivated to get a better grade this semester. (AK).

From AK's statement, indicates that he can control his academic performance by putting forth what he needed strategically to affect on the desired outcomes- understanding science concepts and getting a better grade. In other words, AK is motivated to learn science, because he believes that his efforts will lead to his successful in the national examination (Ujian Nasional).

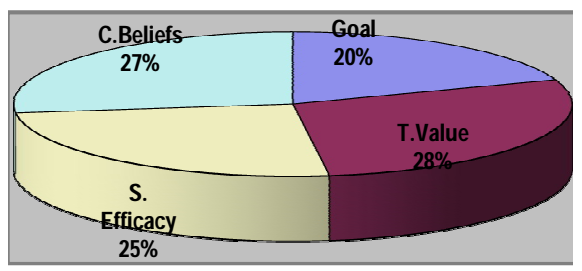

Figure 4. FN's Motivational Factor Profile

Mrs. ED's teaching strategies has also affected FN's learning of science. FN is categorized as a low level of academic performance student in the class. FN feels that the ways of Mrs. ED's teaching that always presents examples and notes, as well as her thorough explanations, help her learn more science ideas. This was indicated by FN in the following statement:

Mrs. ED is one of the best teachers I have ever had! She is such a good teacher because she does examples in front of the class and she explains things thoroughly. She always tries to explain the science materials as clearly as possible. She makes sure we know what we are doing by giving us good notes and examples ( FN).

Figure 4, shows that FN's motivational factor profile consists of $27 \%$ control beliefs, $20 \%$ goal orientation, $28 \%$ task value, and $25 \%$ self-efficacy. FN's motivational factor profile is quite the same as ST's motivational factor profile. The percentage of her motivation factors (control beliefs, goal orientation, task value, and self-efficacy) to learn science almost the same. It indicates that her motivation to learn science is quite low.

Compared to the overall mean of the class, FN's score is slightly below that of the class. In daily classroom activities, FN spent most of her time copying everything Mrs. ED wrote on the white board, although she sometimes asked questions for clarification as well. Mrs. ED frequently came to FN's desk to help her focusing attention on the science materials being offered and to make sure that she understood these materials. From the description above it can be summarized that FN motivation to get involved in learning science was greatly influenced by Mrs. ED's teaching strategies and her personal attention to FN.

The importance of the science course to $\mathrm{RN}$ may lead her to get involved 
in conceptual change learning activities. $\mathrm{RN}$ 's active involvement in learning is supported by her response about what she does to learn science better. In learning science, she developed learning strategies that support her learning effectively.

Like other students, sometimes I do get discouraged, but I know I have to keep going. My classmates encourage me, as well as Mrs. ED, to stick with it and think thorough it. In case, I particularly encounter difficult ideas in science I always either ask my classmates to explain the concepts to me, or ask my teacher to help me more fully understand the ideas (RN).

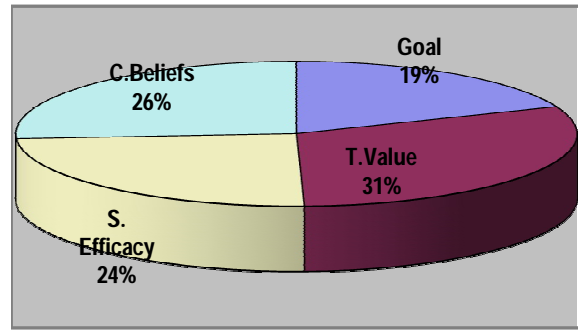

Figure 5. RN's Motivational Factor Profile

RN's motivation factors to learn science consist of $26 \%$ control beliefs, $19 \%$ goal orientation, 31\% task value, and $24 \%$ self-efficacy. She put very low in goal orientation as her motivation factor to learn science (see Figure 5). It indicates, she does not really know the goals she wants to reach by learning science.

Compared to the overall mean of the class, $\mathrm{RN}^{\prime} \mathrm{s}$ score is in the middle that of the class. RN perceives that reviewing notes, doing projects, discussing with classmates, and asking the teacher questions for clarification helped her understand science ideas more fully. She believes that all effort dealing with learning science may lead her to a better understanding of science concepts and that will affect her understanding.

The role of the teacher is very crucial to RK's learning in science. He is categorized as the highest level of academic performance in Mrs. ED's class. RK found that the way a teacher teaches, such as bringing everyday situations to the science concept, and the availability of the simple science equipments. These factors motivate him to get involved in Mrs. ED's science class.

Mrs. ED's explanations and experiments really help to clarity ideas we have learned. Simple science equipments that Mrs. ED-made showed us everyday situations combined with science concepts. She also keeps pushing us to try to explain things for ourselves and think through the problems. In addition, she makes class fun for us so it's not so bored. (RK)

For RK, task value is the most crucial motivational factor to learn science. He perceives that valuing task is very important to bring him succeed in the next of the national examination.

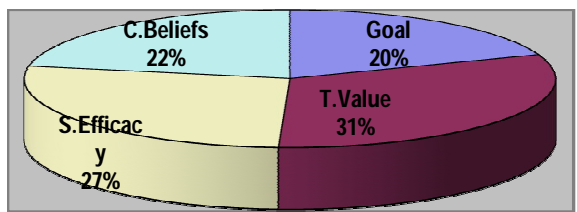

Figure 6. RK's Motivational Factor Profile

RK's motivation factors to learn science consist of $22 \%$ control beliefs, 
$19 \%$ goal orientation, $32 \%$ task value, and $27 \%$ self-efficacy (see Figure 6). Based on his motivational factor profile, task value comes to be the most importance motivation factor for him to learn science, even though, he still does not understand the real goals that he wants to reach by learning science.

Compared to the overall mean of the class, RK's score is slightly above that of the class. In summary, RK is motivated to learn science, because the teaching strategies that Mrs. ED's used and her effort to understand the students' needs, help RK to increase his motivation to learn science.

In other cases, it is found that RV doesn't really like science. It's pictured from the score as the result of the MSLQ test at the bottom 25\% of the class. RV's motivation factors consist of $26 \%$ control beliefs, $21 \%$ goal orientation, $26 \%$ task value, and $27 \%$ self- efficacy. In general, all of the RV's motivation factors percentage quite the same (see Figure 7).

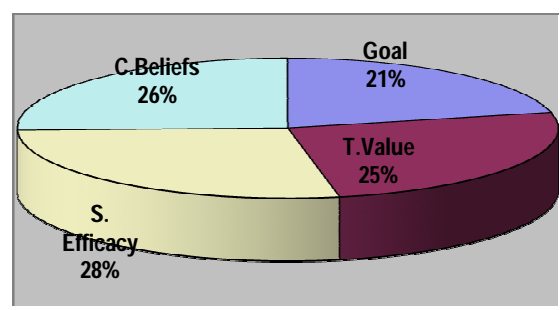

Figure 7. RV's Motivational Factor Profile

Although, RV doesn't really like science, he does put forth the efforts necessary to learn the science concepts Mrs. ED taught. The personal relationship he has with Mrs. ED is an impor- tant reason that motivates $\mathrm{RV}$ to put forth in his best effort. The following statement indicates how important this personal relationship with the teacher to RV.

Mrs. ED's enthusiasm helps me to stick in science course. She helps me to learn. Her high standards for her students also encourage me. She demands the best we can give. We develop such personal relationships with her that we hate to let her down (RV).

In addition, RV comes from the quite wealthy family. He is the only a child in his family, because of that his mother very protected to him that might be effect to his motivation to learn science.

TR is the most talk-active student in the Mrs. ED's class. She is categorized as the middle level of academic performance student in the Mrs ED's class.

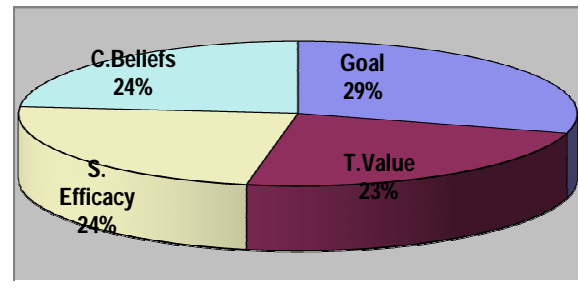

Figure 8. TR's Motivational Factor Profile

TR's motivation factors to learn science consist of $24 \%$ control beliefs, $28 \%$ goal orientation, $24 \%$ task value, and $24 \%$ self-efficacy (see Figure 8). Based on her motivational factor profile, goal orientation comes to be the most importance motivation factor for her to learn science, even though, she still does not understand the real goals 
that she wants to reach by learning science. For her, goal expected is the most crucial motivation factor to learn science. It is related to her expectation of the gift hoped from her parents when she got a good grade in science. Compared to the overall mean of the class, TR's score is below that of the class.

Although, TR's motivation scores slightly below that of the class, Mrs. ED's instruction plays a crucial role on TR's learning. Demonstrations, handson experiments, problem solving practice, and relating materials to real daily life, make Mrs. ED's science class interesting to TR, as she indicates below:

Mrs. ED does a lot of demonstrations and hands-on activities. To learn science well I think this is important because (science) is complex. Lecturing would make the class uninteresting. Also, she has us practice problem a lot. Practice makes perfect!! She (Mrs. ED.) makes material interesting and poses real life questions about what we are studying. Her teaching has led me to look at things differently even outside of the classroom (TR).

The statement above indicates that Mrs. ED's implementation of the variety of class activities, allowing students multiple opportunities to get involved in problem solving, and her extensive supports for students, create a teaching and learning environment that were important for students, especially for TR.

Different from TR, TT is a quiet student in the class and rarely participates in social conversation, even with students sitting next to her tried to engage her. She was indicated as a low level academic performance student in the class. In the group activities, like handson experiments, she worked with her group mates, $\mathrm{DH}$ and $\mathrm{SN}$. TT set up the equipments for the group and the group always worked together quietly. The following is TT's statement of how she used learning strategies to understand science concepts.

I try to find examples of the concept in every day things or I talk to my friends about it and see if they have better understanding they can share with me or I look in [science book] because it is easy to read or I do example problems. A lot of the time I ask Mrs.ED for help in understanding it. Just about all ideas of science are hard to understand, because they are new to me and I have to completely change my perspective on things. (TT)

TT's motivation factors to learn science consist of $27 \%$ control beliefs, $20 \%$ goal orientation, $32 \%$ task value, and $21 \%$ self-efficacy (see Figure 8). Based on her motivational factor profile, task value comes to be the most importance motivation factor for her to learn science. Compared to the overall mean of the class, TT's score is slightly below that of the class. As indicated on her statement above, all of the strategies she used in learning science may lead her to become more involved in conceptual change learning. For TT, getting a good grade, rewards, positive evaluation by other students, and the competition with peers are not her concerns. She tries to learn science very hard just for conceptual understanding. 


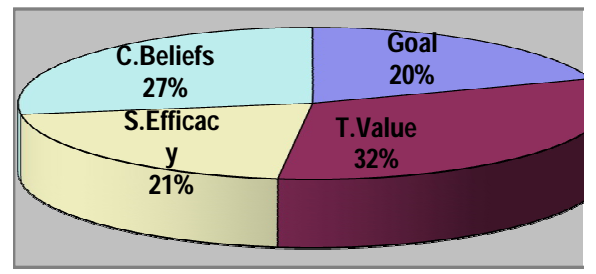

Figure 9. TT's Motivational Factor Profile

In summary, TT is intrinsically motivated to learn science. She is concerned with how interesting, important, and useful science is in her life. She understands that life cannot be divorced from science. She recognizes that science is a tool for understanding phenomena found in the world around her. For these reasons, TT works hard in science class to develop her conceptual understanding of science.

The teacher and TI's classmates play important roles in helping her learn what she can do. Mrs. ED's teaching and TI's classmates lend her valuable support that keeps her trying to learn science.

[In learning science] I frequently get discouraged a lot, but I get encouraged to stick with it by my friends because they understand me, and what we are learning. Also, Mrs. ED makes science fun, so even though I don't understand and have difficulty with it, it can relate some type of ideas with it. (TI)

TI's motivation factors to learn science consist of $27 \%$ control beliefs, $20 \%$ goal orientation, $26 \%$ task value, and $27 \%$ self-efficacy (see Figure 10). Her motivation factor profile shows us that TT does not really like science. Compared to the overall mean of the class, TI's motivation score is slightly below that of the class, but Mrs ED's strategies in teaching science help her to keep engaging in learning science. In most daily class activities, TI spent her time quietly. Mrs. ED frequently assisted her in a group activities and she permanently worked with two other students, RN and FN.

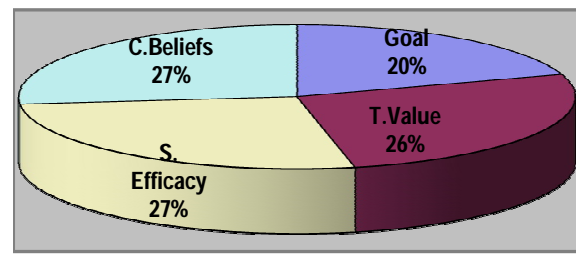

Figure 10. TI's Motivational Factor Profile

From all of the description above, it is clearly pictured that the teacher's unique personality and warmth supported relationship with her students, increase students' motivation to learn science for conceptual understanding.

\section{CROSS CASE ANALYSIS}

From the cross case analysis, students' motivation to learn science for conceptual understanding was greatly influenced by the teacher's uniqueness in the process of teaching and learning. The teacher's personality was found to be the most crucial contribution to motivate student learning. All of students participating in this study mentioned their teacher's personality as the most important factor for them to get involved in the learning process. They agreed that Mrs. ED's sincere love for them as both students and individuals became a powerful extrinsic motivator for 
them to learn for understanding. This finding suggests that developing students-teacher interaction within the social contexts of the classroom is very crucial in the teaching-learning process.

The power of developing positive relationship between teachers and students was that it contributed to motivating students to engage in conceptual change learning is clearly found in the statements made by RV, TI and TT. They were identified as students who do not really like science and placed a low value on the goal of scientific understanding. However, Mrs. ED's success in developing positive personal relationship with these students helped them succeed in developing learning strategies for conceptual understanding. Their lack of interest toward science was reduced by their effort in daily science class activities to satisfy their teacher, "they don't want to let her (Mrs. ED) down" (RV's statement). Consequently, the students were actively engaged in conceptual change learning in daily classroom activities and developed learning strategies such as study parties and after class discussions with the teacher to enhance their understanding of science concepts. This suggests that in the teaching learning process, teachers need to interact with students in the ways that would promote greater engagement within each other and the science content to be learned.

\section{DISCUSSION AND CONCLUSION}

Teachers' personality in teachinglearning process seemed to be the most significant factor to raise students' motivation to learn in meaningful ways, specially for students who have low value in the goal of understanding, negative attitudes toward science, and low quality of task engagement. Although, they got reasonable succeed to get a good grade. For students who have been already intrinsically motivated to learn and high value in the goal of scientific understanding might have been successful without extensive support from the teacher (see $\mathrm{RN}^{\prime} \mathrm{s}$ case). They could have demonstrated high quality of cognitive engagement in learning science independently. However, for students like RV, TI, and TT (about $25 \%$ of the class population) who have low quality of the task engagement, low value in the goal of scientific understanding, and negative attitudes toward science, require extensive teachers' supports necessary to energize their efforts to engage in learning for understanding.

The unique of teacher's personality in teaching and extensive teacher support to the students as needed seem to be the effectively help students' motivation to learn in meaningful ways. The effectiveness of these two factors (teachers' personality and teachers' support) is clearly described, for example in TT, TI, and RV's case. This can be one of the valuable solutions to help these students population to increase their expectations to be accountable for their learning outcomes instead of just finishing the work or course assignment.

Furthermore, the implication of the results of this study for science teachers is to help students to increase their motivation to learn for conceptual change 
through understanding and reducing factors that are identified as the barriers for students' motivation in the social contexts of classrooms. At least, two factors related to students' motivation constrains to engage in conceptual change learning are identified. These constrains include students' lack of value in the goals of scientific understanding, and students' lack of interest in learning science.

\section{ACKNOWLEDGEMENTS}

This research would not have been possible without the help of many people along the way. I would like especially to thank to the Board of National Education Department, the principal, and the sixth grade teacher of The Elementary School Prepared for International Standard Banten Province for their advice, time, understanding, cooperation, and accommodation during this research, and permitted me to gain the rich data for this research. I am also grateful to all of my friends at UPI Serang Campus for their help, encouragement, and valuable suggestions.

\section{REFERENCES}

Anderson, C.W., \& Roth, K. J. 1989. Teaching for Meaningful Understanding and Self-Regulated Learning of Science. In J. Brophy (Ed.), Teaching for Meaningful Understanding and Self-Regulated Learning (h. 265-309). Greenwich, CT: JAI Press.
Barlia, L., \& Beeth, M.E. 1999. High School Students' Motivation to Engage in Conceptual Change-Learning in Science. Paper Presented at the Annual Meeting of the National Association for Research in Science Teaching, Boston, MA, USA.

Beeth, M. E. 1998. "Facilitating Conceptual Change Learning: The Need for Teacher to Support Metacognition". Journal of Science Teacher Education, 9 (1), 49-61.

Beeth, M. E., \& Hewson, P. W. 1997 September. Learning to Learn Science: Instruction that supports Conceptual Change. Paper Presented at the First International Conference of European Science Education Research Association, Rome, Italy.

Blumenfeld, P. C., \& Meece, J. L. 1988. “Task Factors, Teacher Behavior, and Students' Involvement and Use of Learning Strategies in Science". The Elementary School Journal, 88_(3), 235-250.

Boyle, R. A., Magnusson, S. J., \& Young, A. J. 1993. Epistemic motivation and conceptual change. Paper Presented at the Annual Meeting of the National Association for Research in Science Teaching, Atlanta, GA.

Cobb, P., 1994. Constructivism in Math and Science Education. Educational Researcher, 23 (7), p. 4. 
Driver, R., Asoko, H., Leach, J., Mortimer, E., \& Scott, P. 1994. "Constructing Scientific Knowledge in the Classroom". Educational Researcher, 23 (7), 5-12.

Hewson, P. W., Beeth, M.E., \& Thorley, N. R. 1998. "Conceptual Change Teaching". In B. J. Fraser and K. G. Tobin(Eds.).International Handbook of Science Education. Dordrecht, The Netherlands: Kluwer Academic Publishers.

Lee, O., \& Anderson, C. W. 1993. Task "Engagement and Conceptual Change in Middle School Science Classrooms". American Educational Research Journal, 30_(3), 585610.

Lee, O., \& Brophy, J. 1996. Motivational "Patterns Observed in Sixth-Grade Science Classrooms". Journal of
Research in Science Teaching, 33 (3), 303-318.

Pintrich, P. R., \& Schrauben, B. 1992. "Students' Motivational Beliefs and Their Cognitive Engagement in Classroom Academic Tasks". In D. Schunk \& J. Meece (Eds.), Student Perceptions in the Classroom: Causes and Consequences. Hillsdale. NJ: Erlbaum

Posner, G.J. 1982. “A Cognitive Sciene Conception of Curriculum and Instruction". Curriculum Studies, 14 (4). hlm. 343-351.

Pintrich, P. R., Smith, D. A., Garcia, T., \& McKeachie, W. J. 1991. A Manual for the Use of Motivated Strategies for Learning Questionnaire (MSLQ). National Center for Research to Improve Post-Secondary Teaching and Learning, Ann Arbor, MI. 